\title{
Causative organism of paralytic shellfish toxins other than toxic dinoflagellates
}

\author{
Setsuko Sakamoto ${ }^{1}$, Takehiko Ogata ${ }^{1}$, Shigeru Sato ${ }^{1}$, Masaaki Kodama ${ }^{1, *}$, \\ Terufumi Takeuchi ${ }^{2}$
}

\footnotetext{
${ }^{1}$ Laboratory of Marine Biological Chemistry, School of Fisheries Sciences, Kitasato University, Sanriku, Iwate 022-01, Japan

${ }^{2}$ Wakayama Prefectural Fisheries Experimental Station, Kushimoto, Wakayama 649-35, Japan
}

\begin{abstract}
Bivalve toxicity and the abundance of Alexandrium catenella were monitored in association with the toxicity of particles in seawater During the bloom of $A$. catenella, bivalve toxicity increased. However, no significant amount of toxins was detected in natural $A$. catenella cells during the period. In contrast, particles smaller than $A$. catenella possessed a considerable amount of paralytic shellfish toxins (PSP toxins). These facts showed that unknown causative organism(s) of PSP toxins, of smaller size than the dinoflagellates, occurred during the bloom of $A$. catenella
\end{abstract}

\section{INTRODUCTION}

Paralytic shellfish poisoning (PSP) is one of the global problems caused by dinoflagellates. Causative organisms for PSP are several species of dinoflagellates such as Alexandrium tamarense and A. catenella (Schantz 1986) (equal to former Protogonyaulax; Steidinger \& Moestrup 1990). When these species bloom in the environment, bivalves accumulate toxins by ingesting them. It has been confirmed by many researchers that bivalves become toxic during blooms of toxic dinoflagellates (Needler 1949, Kawabata et al. 1962, Ferraz-Reyes et al. 1985, Therriault et al. 1985, Bravo et al. 1990). In a monitoring survey on bivalve toxicity and abundance of toxic dinoflagellates in Ofunato Bay (Japan) during 1980 and 1986, we also confirmed the accumulation of toxin by bivalves during the bloom of dinoflagellates (Sekiguchi et al. 1989). However, we noticed at the same time that these 2 occurrences are not always parallel to each other (Ogata et al. 1982). Bivalve toxicity often increased significantly in the absence of toxic dinoflagellates, suggesting the presence of unknown causative organism(s) other than dinoflagellates. A similar phenomenon has been observed

- Addressee for correspondence by one of the authors ( $\mathrm{T}$. Takeuchi) in Tanabe Bay (Japan) where A. catenella blooms every year (unpubl. data). In this case, bivalve toxicity often increases almost in no relation with abundance of $A$. catenella. Previously, we reported that PSP toxins are detected in particles of bacterial size in the seawater during the period when bivalve toxicity was increasing in absence of toxic dinoflagellates (Kodama et al. 1990). From these, we suggested that marine bacteria which produce PSP toxins are also the causative organisms for bivalve toxicity. In the present study, we monitored the bivalve toxicity in association with the toxicity of particles with smaller size in the environmental seawater in Tanabe Bay. We report here that much of PSP toxins was often observed in particle fractions which are smaller than A. catenella.

\section{MATERIALS AND METHODS}

Recovery of Alexandrium catenella cells. A. catenella isolated from Tanabe Bay was cultured in T1 medium (Ogata et al. 1987) at $20^{\circ} \mathrm{C}$ under a light intensity of $45 \mu \mathrm{E} \mathrm{m}^{-2} \mathrm{~s}^{-1}$. During culture, portions were taken out at the lag, exponential and stationary growth phases. The culture of $A$. catenella was filtered successively through the filter sieves with pore sizes of 
20 and $5 \mu \mathrm{m}$. Cells recovered on each filter were counted under the microscope. Toxicity of the cells in these fractions was analyzed by mouse bioassay using dose-death time table for saxitoxin (STX) (Sommer \& Meyer 1937) and a high performance liquid chromatography (HPLC) fluorometric analysis for PSP toxins (Oshima et al. 1989). Toxicity was expressed as mouse units (MU), where $1 \mathrm{MU}$ is the dose required to kill a $20 \mathrm{~g}$ male mouse (strain ddY) in $15 \mathrm{~min}$.

Alexandrium catenella abundance and shellfish toxicity. Non-toxic specimens of the scallop Chlamys nobilis were transplanted at $1 \mathrm{~m}$ depth in a net hanging from a float set at the sampling station in Tanabe Bay. Five specimens of scallop were taken 1 to 5 times a month from January to June 1990. The toxicity of the digestive gland was measured by mouse bioassay (Kawabata 1978) and expressed as MU as described above. At the same time, 11 of seawater was collected from the surface to $8 \mathrm{~m}$ depth $11 \mathrm{~m}$ above the bottom) at $2 \mathrm{~m}$ intervals. Collected seawater was concentrated to $20 \mathrm{ml}$ by gravity filtration through a $5 \mu \mathrm{m}$ membrane filter. $A$. catenella cells in $1 \mathrm{ml}$ from each $20 \mathrm{ml}$ concentrate were counted under a light microscope.

Toxicity of particle fractions. At the same time as shellfish and seawater samples were collected, $100 \mathrm{l}$. seawater was taken from the surface. Particles suspended in the seawater were fractionated by successive filtration through 20,5 and $0.45 \mu \mathrm{m}$ filters. Three particle fractions, $>20,5-20$ and 0.45-5 $\mu \mathrm{m}$ fractions, were obtained and extracted with $80 \%$ ethanol containing $0.03 \mathrm{M}$ acetic acid. After removal of ethanol by evaporation, the extracts were defatted with dichloromethane. PSP toxins in these extracts were analyzed by HPLC equipped with a fluorometric detector (Oshima et al. 1989). Portions of the extracts were also analyzed for toxicity by mouse bioassay.

Toxin identification. PSP toxins in the particle fraction with high toxicity were purified by chromatography with Bio-Gel P-2 and Bio-Rex 70 (Kotaki et al. 1981). Purified toxins were analyzed by
TLC (Kotaki et al. 1981), cellulose acetate membrane electrophoresis (Fallon \& Shimizu 1977) and HPLC-fluorometric analysis for PSP toxins (Oshima et al. 1989). The fast atom bombardment mass spectrum (FAB-MS) of the purified toxins was measured using glycerol as the matrix.

\section{RESULTS}

\section{Recovery of Alexandrium catenella cells}

Table 1 shows the number of Alexandrium catenella cells recovered by each filter, their actual sizes measured under light microscope, and the toxicity of the cells. Most cells measured under the microscope were larger than $30 \mu \mathrm{m}$. However, a small number of the cells passed through the $20 \mu \mathrm{m}$ net, showing the presence of the cells which passed through pores smaller than the cells themselves. The proportion of the number of cells which passed through the $20 \mu \mathrm{m}$ net to the total number of cells was highest at the exponential phase and lowest at the stationary phase. However, more than $99 \%$ of the cells were recovered by the net at any growth stage.

The toxicity of the cells recovered by the $20 \mu \mathrm{m}$ net was highest at the lag phase. It decreased at the exponential and stationary phases. However, the toxicity of these cells was higher than that of the cells which passed through the filter. On the other hand, the cells which passed through the net at stationary phase showed exceptionally high toxicity similar to that of the cells recovered by the sieve at lag phase. However, nearly all of the toxicity originating from Alexandrium catenella was recovered by the $20 \mu \mathrm{m}$ filter, as shown in Table 1 .

\section{Alexandrium catenella abundance and shellifish toxicity}

Fig. 1A shows the seasonal variation of vertical distribution of Alexandrium catenella. During the bloom, A. catenella was observed in the seawater

Table 1. Alexandrium catenella. Number and the toxicity of cells recovered by the $20 \mu m$ sieve. MU: mouse units (see 'Materials and methods'); -: no data; ND: not detected

\begin{tabular}{|c|c|c|c|c|c|c|c|}
\hline \multirow[t]{2}{*}{ Growth stage } & \multirow{2}{*}{$\begin{array}{l}\text { Harvest } \\
\text { (l) }\end{array}$} & \multirow[t]{2}{*}{ Fraction } & \multicolumn{2}{|c|}{ Cells } & \multirow{2}{*}{$\begin{array}{l}\text { Cell size } \\
(\mu \mathrm{m})\end{array}$} & \multicolumn{2}{|c|}{ Toxicity } \\
\hline & & & No. & $\%$ & & (MU $10^{-4}$ cells) & $\left(\mathrm{MU} \mathrm{l}^{-1}\right)$ \\
\hline Lag phase & 2.1 & $\begin{array}{l}>20 \mu \mathrm{m} \\
5-20 \mu \mathrm{m}\end{array}$ & $\begin{array}{l}1.77 \times 10^{5} \\
1.12 \times 10^{3}\end{array}$ & $\begin{array}{r}99.37 \\
0.63\end{array}$ & $\begin{array}{c}- \\
29.1 \pm 5.20\end{array}$ & $\begin{array}{l}0.93 \\
\text { ND }\end{array}$ & $\begin{array}{l}0.79 \\
\text { ND }\end{array}$ \\
\hline Exponential phase & 1.0 & $\begin{array}{l}>20 \mu \mathrm{m} \\
5-20 \mu \mathrm{m}\end{array}$ & $\begin{array}{l}2.47 \times 10^{5} \\
2.47 \times 10^{4}\end{array}$ & $\begin{array}{r}99.01 \\
0.99\end{array}$ & $\begin{array}{l}33.5 \pm 4.56 \\
31.5 \pm 3.08\end{array}$ & $\begin{array}{l}0.05 \\
0.02\end{array}$ & $\begin{array}{r}13.80 \\
0.05\end{array}$ \\
\hline Stationary phase & 0.7 & $\begin{array}{r}>20 \mu \mathrm{m} \\
5-20 \mu \mathrm{m}\end{array}$ & $\begin{array}{l}1.46 \times 10^{7} \\
6.23 \times 10^{3}\end{array}$ & $\begin{array}{r}99.96 \\
0.04\end{array}$ & $\begin{array}{l}33.2 \pm 3.19 \\
30.3 \pm 3.49\end{array}$ & $\begin{array}{l}0.10 \\
0.89\end{array}$ & $\begin{array}{r}214.17 \\
0.80\end{array}$ \\
\hline
\end{tabular}


Fig. 1 Seasonal variation of Alexandrium catenella abundance, scallop toxicity and the toxicity of particle fractions from January to June 1990 in Tanabe Bay. (A) Vertical distribution of $A$. catenella. Cell density (cells $\left.1^{-1}\right):(\square) 0$ to $99 ;(0)$ 100 to 999 ; (䀦) 1000 to 4999 ; (NV) 5000 to 9999 ; (目) $>10000$. (B) Abundance of A. catenella ( $\bullet$, no. of cells) and scallop toxicity (o, MU $\left.\mathrm{g}^{-1}\right)$. A. catenella were collected from 1 i samples taken every $2 \mathrm{~m}$ from the surface to $8 \mathrm{~m}$ depth. Arrows: peaks of $A$. catenella abundance where shellfish toxicity is decreasing. (C) Toxicity of particle fractions: $(\square)>20 \mu \mathrm{m}$; (A) 5-20 $\mu \mathrm{m}$; (О) $0.45-5 \mu \mathrm{m}$
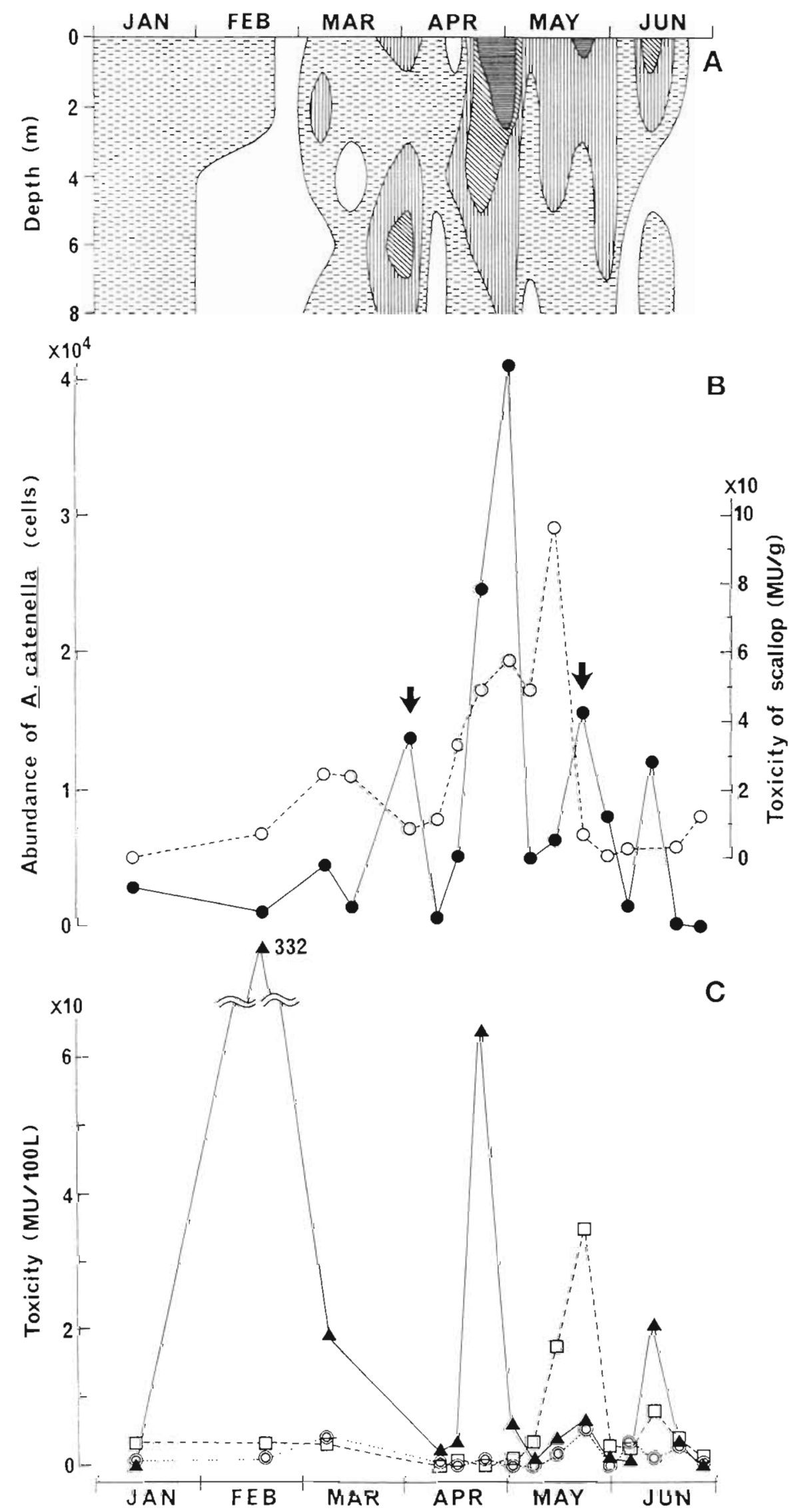
from surface to bottom, with highest density between the surface and $2 \mathrm{~m}$ depth. As shown in Fig. 1B, A. catenella increased with fluctuations from March to June. The maximum abundance was observed on May 1 It disappeared at the end of June. Scallop toxicity increased with increase of the abundance of A. catenella. However, these 2 parameters were not always parallel to each other. Bivalve toxicity was observed to decrease when $A$. catenella density was increasing (arrows in Fig. 1B).

\section{Toxicity of particle fractions}

Fig. 1C shows the seasonal variation of the toxicity of particle fractions. It is noteworthy that the toxicity of the $>20 \mu \mathrm{m}$ fraction which includes that of Alexandrium catenella was not significant from January to May 22, while growth peaks of $A$. catenella, including the maximum (May 1), were observed during that period. These facts show that A. catenella which occurred before May 22 did not contain significant amounts of toxin. On the other hand, the toxicity of the 5-20 $\mathrm{m}$ fraction showed marked peaks on February 19 and April 23, and did not coincide with those of $A$. catenella abundance. The toxicity of the $0.45-5 \mu \mathrm{m}$ fraction was not significant over the period of the survey.

\section{Toxin identification}

Fig. 2 shows the chromatograms of HPLCfluorometric analyzer (Oshima et al. 1989) of particle fractions collected on February 19. Peaks with identical retention time with gonyautoxin (GTX) 1 to 4 , STX and neoSTX were observed in the $5-20$ and $>20 \mu \mathrm{m}$ fractions. Those of GTX 1,4 and STX were detected in the $0.45-5 \mu \mathrm{m}$ fraction. The toxin amount of the $5-20 \mu \mathrm{m}$ fraction obtained from 100 I seawater on February 19 was 332 MU based on HPLC analysis. The toxicity by mouse bioassay coincided with that of HPLC analysis. The toxins in this fraction were purified by column chromatography with Bio-Gel P-2 and Bio-Rex 70. By repeating Bio-Rex 70 column chromatography, the mixture of GTX 2 and 3 (which are isomers) was highly purified. As shown in Fig 3, the purified toxins showed identical behavior to authentic toxins in TLC and cellulose acetate membrane electrophoresis. The FAB-MS scan of purified toxins (Fig. 4) shows that the mixture of toxins had an identical ion peak to that of the pseudomolecular ion $(\mathrm{M}-\mathrm{H})^{-}$of GTX 2 and 3 at $m / z=394$ (Maruyama et al. 1984). On this basis, we concluded that the toxins detected here by HPLC analysis (Fig. 2) were PSP toxins.

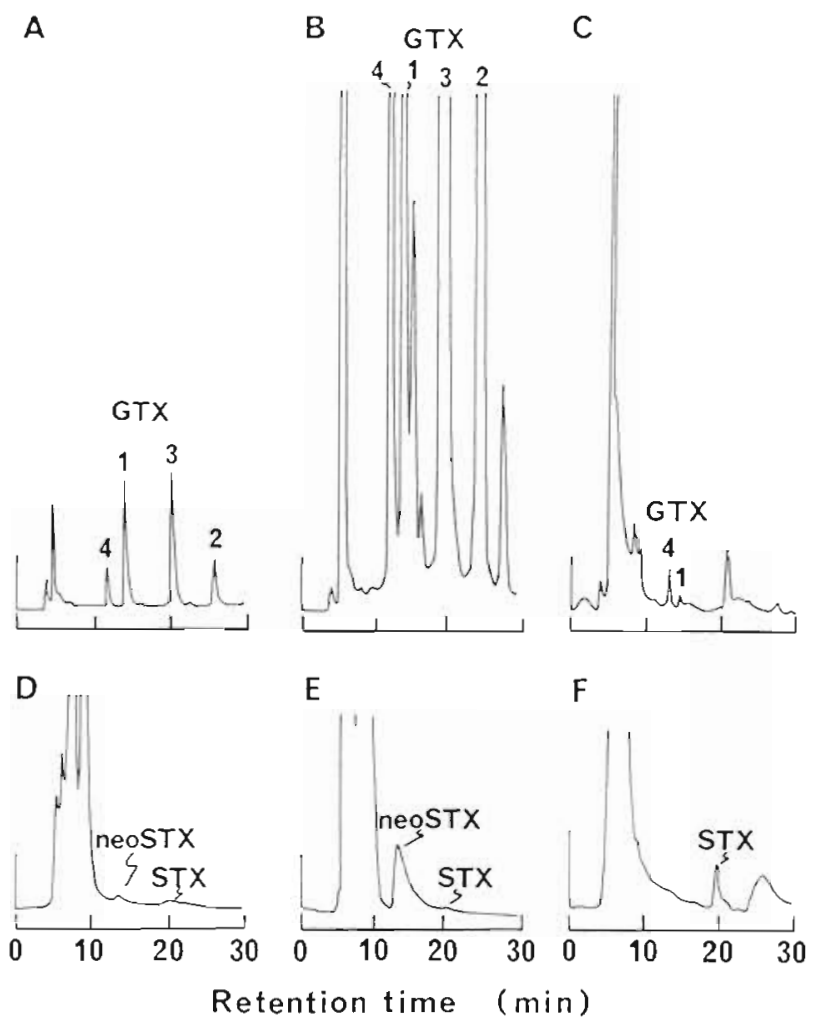

Fig. 2. HPLC-fluorometric analysis of the extracts of particle fractions from the seawater collected on February 19 , 1990. Mobile phase for (A), (B) \& (C): $2 \mathrm{mM}$ 1-heptanesulfonic acid/10 mM phosphoric acid ( $\mathrm{pH} 7.2$ ); mobile phase for (D), (E) \& (F): 2 mM 1-heptanesulfonic acid / 10 $\mathrm{mM}$ phosphoric acid $/ 10 \%$ acetonitrile $(\mathrm{pH} 7.2)$. (A) \& (D): $>20 \mu m_{i}(B) \&(E): 5-20 \mu m_{i}(C) \&(F): 0.45-5 \mu m$. STX: saxitoxin; GTX 1 to 4 : gonyautoxin 1 to 4

\section{DISCUSSION}

Alexandrium catenella is a unicellular globular organism with 21 to $48 \mu \mathrm{m}$ length and width (Fukuyo 1985). Previously, we reported that considerable number of cells larger than $30 \mu \mathrm{m}$ passed through a $30 \mu \mathrm{m}$ sieve, showing the presence of the cells which pass through pores smaller than the cells themselves (Kodama et al. 1982). Before fractionation of the particles in the seawater through the sieves with different mesh sizes, we examined the recovery of A. catenella cells by the $20 \mu \mathrm{m}$ net, using cultured cells of A. catenella isolated from Tanabe Bay. Nearly all cells (more than $99 \%$ ) were found to be recovered by the $20 \mu \mathrm{m}$ net. The toxicity of the recovered cells was highest at lag phase but decreased considerably at exponential and stationary phase. These data were similar to those reported by other authors (Prakash 1967, White \& Maranda 1978, Oshima \& Yasumoto 1979, Singh et al. 1982, Boyer et al. 1985). 
a

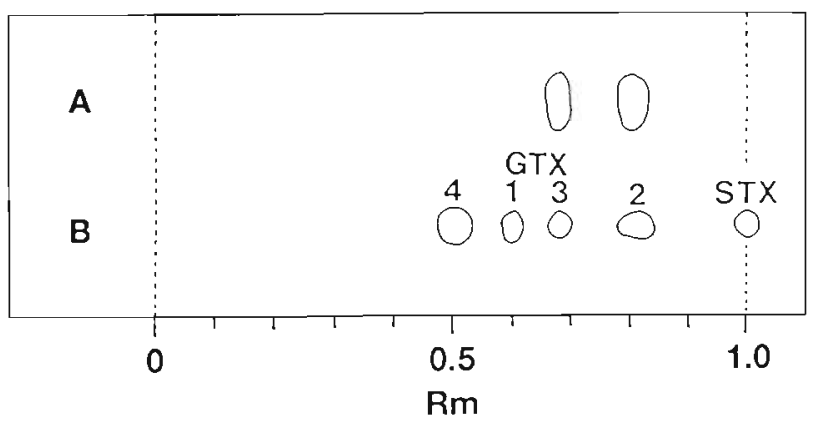

b

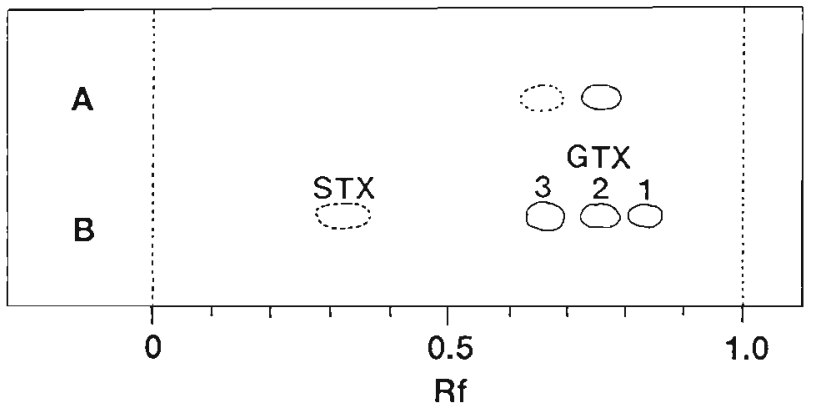

Fig. 3. Identification of purified toxins from the 5-20 $\mu \mathrm{m}$ particle fraction on February 19. (a) Electrophoresis conducted on $6 \times 18 \mathrm{~cm}$ cellulose acetate membrane in $0.08 \mathrm{M}$ Tris-HCl buffer $(\mathrm{pH} 8.7)$ at $0.8 \mathrm{~mA} \mathrm{~cm}^{-1}$ for $20 \mathrm{~min}$. Detection of toxins was viewed under UV light after spraying $1 \%$ hydrogen peroxide and heating at $120^{\circ} \mathrm{C}$ for $5 \mathrm{~min}$. A: Purified toxins; B: authentic specimens of PSP toxins; other symbols as in Fig. 3. (b) TLC, with toxins developed on a Silica gel 60 precoated plate with a solvent system of pyridine : ethyl acetate: acetic acid : water $(75: 35: 15: 30)$. Detection of toxins and symbols as above

A small number of cells were found to pass through the $20 \mu \mathrm{m}$ sieve. Microscopic observation of these cells, however, revealed all of them to be larger than $20 \mu \mathrm{m}$. The toxicity of these cells at the lag and exponential phases was much less than that of the cells recovered by the $20 \mu \mathrm{m}$ sieve. In contrast, the cells which passed through the $20 \mu \mathrm{m}$ net at the stationary phase showed exceptionally high toxicity similar to that of the cells recovered by the $20 \mu \mathrm{m}$ sieve at the lag phase. However, the toxicity of the cells which passed through the $20 \mu \mathrm{m}$ sieve was negligible because the number of the cells was less than $1 \%$. Therefore, the toxicity originating from Alexandrium catenella was considered to be recovered in the $>20 \mu \mathrm{m}$ fraction in the field survey.

Interestingly, the $>20 \mu \mathrm{m}$ particle fraction collected from Tanabe Bay did not show any significant toxicity during January and the beginning of May, when Alexandrium catenella showed marked growth. The toxicity was not detected in this fraction even when A. catenella showed maximum growth at May 1 but increased slightly at the growth peak on May 22. We found that the isolate from Tanabe Bay showed significant toxicity when cultured. These findings show that $A$. catenella cells blooming in the bay are not always toxic. Although the effect of various environmental factors on the toxicity of cultured dinoflagellate cells has been studied by many authors (White 1978, Boyer et al. 1985, Ogata et al. 1987), little is known on the seasonal variation in the toxicity of natural dinoflagellate cells. Our data show that the toxicity of $A$. catenella cells varies in a wide range in nature. Toxin content as well as dinoflagellate cell density are important factors for bivalve toxicity. Thus attention should be focused on both factors in future field surveys.

During the period when the bivalve toxicity was increasing, the $5-20 \mu \mathrm{m}$ fraction often showed considerable toxicity. Only this fraction showed significant toxicity in this period, indicating that bivalves accumulated the toxin from this fraction. On February 19, the toxicity of this fraction markedly increased and reached a maximum. Chemical analysis revealed that the toxic principles of this fraction were PSP
Fig. 4. Negative FAB-MS of the toxin isolated from the $5-20 \mu \mathrm{m}$ particle fraction on February 19. The ion peak observed at $\mathrm{m} / \mathrm{z}=394$ is identical to that of the pseudomolecular ion $(\mathrm{M}-\mathrm{H})^{-}$of GTX 2 and 3. A fragment ion observed at $\mathrm{m} / \mathrm{z}=183$ is assigned to be (2 glycerol $-\mathrm{H}$ )
(\%)

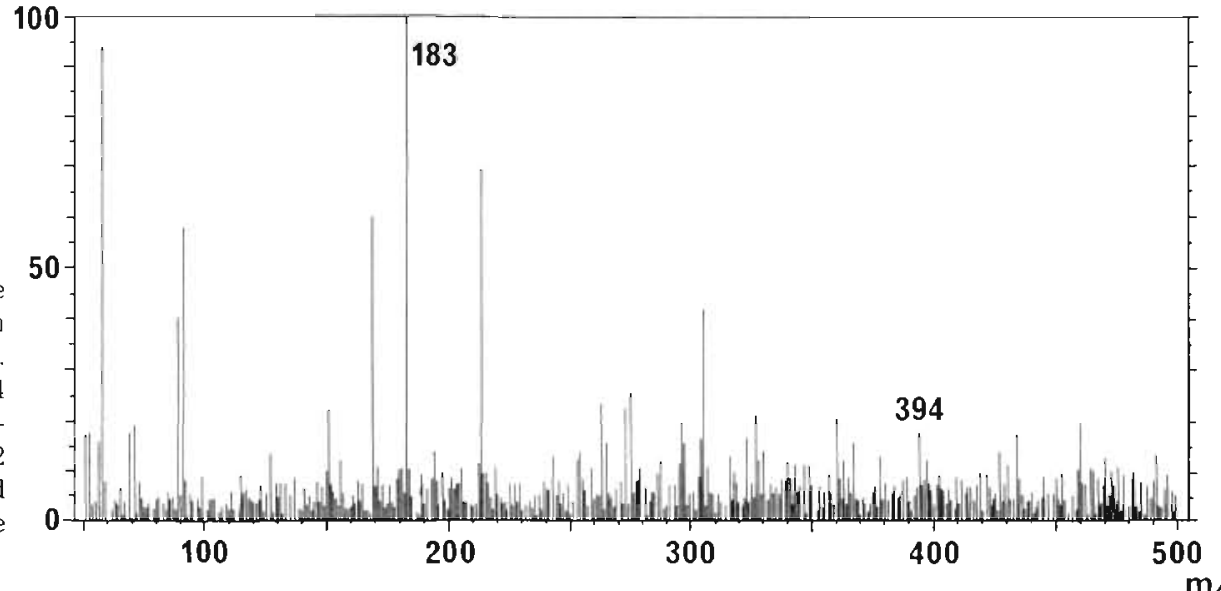


toxins. These results show the presence of the unknown causative organism(s) of PSP toxins, the size of which is smaller than Alexandrium catenella in Tanabe Bay.

It has been known that bivalves accumulate PSP toxins during blooms of toxic dinoflagellates. Production of PSP toxins by the isolated and cultured dinoflagellates has been confirmed by many authors (Oshima et al. 1977, Hall et al. 1980, Fix Wichmann et al. 1981, Harada et al. 1982, Noguchi et al. 1983). From these, it has been generally accepted that shellfish toxins originate from the dinoflagellates. However, the present data show that the unknown causative organism(s) of the toxin also occurs together with Alexandrium catenella in the same environment and makes the shellfish toxic. Seemingly the presence of the unknown causative organism(s) other than dinoflagellates has been overlooked, probably because this organism occurs together with toxic dinoflagellates. The small size of the organism compared to the dinoflagellate may be another reason it is overlooked.

In the previous study at Ofunato Bay, we reported that a considerable amount of PSP toxins was detected in the $0.45-5 \mu \mathrm{m}$ particle fraction in which most of bacteria are trapped. From this fact, together with occurrence of toxin-producing bacteria in this fraction, we suggested that the origin of PSP toxins in this fraction is bacteria (Kodama et al. 1990). On the other hand, PSP toxins were found in 5-20 $\mu \mathrm{m}$ fraction of the present study in Tanabe Bay. Although we did not examine what organisms were in this fraction, small ciliates or flagellates, if present, would be trapped in the fraction. These organisms often ingest other plankton larger than themselves as well as bacteria (Capriulo et al. 1991. Sanders 1991). Thus, PSP toxins detected in this fraction may originate from Alexandrium catenella or PSP toxins-producing bacteria through small ciliates or flagellates. On the other hand, few organisms were observed in the seawater sample at the time when the 5-20 $\mu \mathrm{m}$ particle fraction showed high toxicity. Instead, many detritus and silt particles were observed in the sample. Tanabe Bay is a shallow and open bay whereas Ofunato Bay is a deep and waveless bay, the mouth of which is closed by the breakwaters against 'tsunami', or seismic tidal waves. Therefore, the density of suspended silt or detritus in Tanabe Bay seems to be higher than in Ofunato Bay. PSP toxins in the 5-20 $\mu \mathrm{m}$ fraction may originate from bacteria attaching to these particles. Future field surveys on bivalve toxicity should be conducted paying attention not only to known toxic dinoflagellates but to the toxic organisms in smaller particle fractions.
Acknowledgements. We are grateful to Dr M. Murakami, Associate Professor at Tokyo University, Faculty of Agriculture, for measurement of FAB-MS. This work was partly supported by grants from Ministry of Agriculture. Fishery and Forestry, and from Ministry of Education, Science and Culture of Japan.

\section{LITERATURE CITED}

Boyer, G. L., Sullivan, J. J., Andersen, R. J., Harrison, P. J., Taylor, F. J. R. (1985). Toxin production in three isolates of Protogonyaulax sp. In: Anderson, D. M., White, A. W. Baden, D. G. (eds.) Toxic dinoflagellates. Elsevier, New York, p. 281-286

Bravo, I., Reguera, B., Martinez, A., Fraga, S. (1990). First report of Gymnodinium catenatum Graham on the Spanish Mediterranean coast. In: Granéli, E., Sundström, B., Elder, L., Anderson, D. M. (eds.) Toxic marine phytoplankton. Elsevier, New York, p. 449-452

Capriulo, G. M., Sherr, E. B., Sherr, B. F. (1991). Trophic behaviour and related community feeding activities of heterotrophic marine protists. In: Reid, P. C., Turley, C. M., Burkill, P. H. (eds.) Protozoa and their role in marine processes, NATO ASI Series G: Ecological Sciences, Vol. 25. Springer-Verlag, Berlin, p. 219-265

Fallon, W. E., Shimizu, Y. (1977). Electrophoretic analysis of paralytic shellfish toxins. J. environ. Sci. Health A12: $455-464$

Ferraz-Reyes, E., Reyes-Vasquez, G., Amelia, L. O. (1985). Dinoflagellates of the genera Gonyaulax and Protogonyaulax in the Gulf of Cariaco, Venezuela. In: Anderson, D. M., White, A. W., Baden, D. G. (eds.) Toxic dinoflagellates. Elsevier, New York, p. 69-72

Fix Wichmann, C., Niemczura, W. P., Schnoes, H. K. (1981). Structures of two novel toxins from Protogonyaulax. J. Am. Chem. Soc. 103: 6977-6978

Fukuyo, Y (1985). Morphology of Protogonyaulax tamarensis (Lebour) Taylor and Protogonyaulax catenella (Whedon and Kofoid) Taylor trom Japanese coastal waters. Bull. mar Sci. 37: 529-537

Hall, S., Reichart, P. B., Neve, R. A. (1980). Toxins extracted from an Alaskan isolate of Gonyaulax sp. Biochem. Biophys. Res. Comm. 97: 649-653

Harada, T., Oshima, Y., Yasumoto, $T$ (1982). Structures of two paralytic shellfish toxins, Gonyautoxins $V$ and $V I$, isolated from a tropical dinoflagellate, Pyrodinium bahamense var. compressa. Agric. biol. Chem. 46: $1861-1864$

Kawabata, T. (1978). Assay method for paralytic shellfish poison. In: Environmental Health Bureau, Ministry of Health and Welfare (ed.) Manual for methods of food sanitation testing, Vol II. Japan Food Hygiene Association, Tokyo, p. 240-244

Kawabata, T., Yoshida, T., Kubota, Y (1962). Paralytic shellfish poison - I. A note on the shellfish poisoning occurred in Ofunato City, Iwate Prefecture in May, 1961 Nippon Suisan Gakk. 28: 344-351

Kodama, M., Fukuyo, Y., Ogata, T., Igarashi, T., Kamiya, H., Matsuura, F. (1982). Comparison of toxicities of Protogonyaulax cells of various sizes. Nippon Suisan Gakk. 48: 567-571

Kodama, M., Ogata, T., Sato, S., Sakamoto, S. (1990). Possible association of marine bacteria with paralytic shellfish toxicity of bivalves. Mar. Ecol. Prog. Ser 61 $203-206$

Kotaki, Y., Oshıma, Y., Yasumoto, T (1981). Analysis of 
paralytic shellfish toxins of marine snails. Nippon Suisan Gakk. 47: 943-946

Maruyama, J., Noguchi, T., Matsunaga, S., Hashimoto, K. (1984). Fast atom bombardment-and secondary ionmass spectrometry of paralytic shellfish poisons and tetrodotoxin. Agric biol. Chem 48: 2783-2788

Needler, A. B. (1949). Paralytic shellfish poisoning and Gonyaulax tamarensis. J. Fish. Res. Bd Can. 7: 490-504

Noguchi, T., Onoue, Y., Maruyama, J., Hashimoto, K., Nishio, S., Ikeda, T (1983). The new paralytic shellfish poisons from P. catenella. Nippon Suisan Gakk. 49: 1931

Ogata, T., Ishimaru, T., Kodama, M. (1987). Effect of water temperature and light intensity on growth rate and toxicity change in Protogonyaulax tamarensis. Mar. Biol. 95: $217-220$

Ogata, T., Kodama, M., Fukuyo, Y., Inoue, T., Kamiya, H., Matsuura, F., Sekiguchi, K., Watanabe, S. (1982). The occurrence of Protogonyaulax spp. in Ofunato Bay, in association with the toxification of the scallop Patinopecten yessoensis. Nippon Suisan Gakk. 48: 563-566

Oshima, Y., Buckley, L., Alam, M., Shimizu, Y. (1977). Heterogeneity of paralytic shellfish poisons. Three new toxins from cultured Gonyaulax tamarensis, Mya arenaria, and Saxidomus giganteus. Comp. Biochem. Physiol. 57. 31-34

Oshima, Y., Sugino, K., Yasumoto, T. (1989). Latest advances in HPLC analysis of paralytic shellfish toxins. In: Natori, S., Hashimoto, K., Ueno, Y. (eds.) Mycotoxins and phycotoxins '88. Elsevier, Amsterdam, p. 319-326

Oshima, Y., Yasumoto, T. (1979). Analysis of toxins in cultured Gonyaulax excavata. In: Taylor, D. L., Seliger, H. H. (eds.) Toxic dinoflagellate blooms. Elsevier, New York, p. 377-380

Prakash, A. (1967). Growth and toxicity of a marine dinoflagellate, Gonyaulax tamarensis. J. Fish. Res. Bd Can. 24: $1589-1606$

Sanders, R. W. (1991). Trophic strategies among hetero-

This article was submitted to the editor trophic flagellates. In: Patterson, D. J., Larsen, J. (eds.) The biology of free-living heterotrophic flagellates. The Systematics Association Special Vol. No. 45. Clarendon Press, Oxford, p. 21-38

Schantz, E. J. (1986). Chemistry and biology of saxitoxin and related toxins. Annls. N.Y. Acad. Sci. 479: 15-23

Sekiguchi, K., Inoguchi, N., Shimizu, M., Saito, S., Watanabe, S., Ogata, T., Kodama, M., Fukuyo, Y (1989). Occurrence of Protogonyaulax tamarensis and shellfish toxicity in Ofunato Bay from 1980-1986. In: Okaichi, T., Anderson, D. M., Nemoto, T (eds.) Red tides: biology, environmental science, and toxicology. Elsevier, New York, p. 399-402

Singh, H. T., Oshima, Y., Yasumoto, $\Upsilon$ (1982). Growth and toxicity of Protogonyaulax tamarensis in axenic culture. Nippon Suisan Gakk. 48: 1341-1343

Sommer, H., Meyer, K. F. (1937). Paralytic shellfish poisoning. Arch. Pathol. 24: 560-598

Steidinger, K. A., Moestrup, O. (1990). The taxonomy of Gonyaulax, Pyrodinium, Alexandrium, Gessnerium, Protogonyaulax and Goniodoma. In: Graneli, E., Sundström, B., Elder, L., Anderson, D. M. (eds.) Toxic marine phytoplankton. Elsevier, New York, p. 522-523

Therriault, J. C., Painchaud, J., Levasseur, M. (1985). Factors controlling the occurrence of Protogonyaulax tamarensis and shellfish toxicity in the St. Lawrence Estuary: freshwater runoff and the stability of the water column. In: Anderson, D. M., White, A. W., Baden, D. G. (eds.) Toxic dinoflagellates. Elsevier, New York, p. $141-146$

White, A. W. (1978). Salinity effects on growth and toxin content of Gonyaulax excavata, a marine dinoflagellate causing paralytic shellfish poisoning $J$ Phycol. 14 $475-479$

White, A. W., Maranda, L. (1978). Paralytic toxins in the dinoflagellate Gonyaulax excavata and in shellfish. J. Fish. Res. Bd Can. 35: 397-402

Manuscript first received: September 17, 1991 Revised version accepted: October 7, 1992 